\title{
Measurement of Acetylcholine from Cell Lines
}

\author{
Jamie K. Lau, Kathleen C. Brown and Piyali Dasgupta*
}

Department of Pharmacology, Physiology, and Toxicology, Marshall University, Huntington, USA *For correspondence: dasgupta@marshall.edu

[Abstract] Cigarette smoking is the leading risk factor for the development of lung cancer. It is estimated that smoking is associated with $80-90 \%$ of lung cancer cases throughout the world (see References 1 and 2). The addictive component of cigarette smoke is nicotine. Our published data shows that nicotine promotes the production of acetylcholine (ACh) in human bronchioalveolar carcinoma cells (BACs) (Lau et al., 2013). ACh functions as a growth factor in human BACs. The following protocol is based on a published protocol by (Song et al., 2003), with some modifications (Lau et al., 2013; Song et al., 2008; Song et al., 2003; Sekhon et al., 2003). An important point to remember is that fetal bovine serum (FBS) contains a high amount of acetylcholine (ACh). Therefore, cells must be cultured in serum-free medium to measure ACh in the culture supernatant. Two aliquots of the culture supernatant are used for analysis. This protocol measures the total choline in the cell supernatent under two conditions: 1) After treatment with acetylcholinesterase (AChE), which converts the ACh to choline (also called the total choline sample) and 2) after measuring the amount of free choline in the sample. The concentration of $\mathrm{ACh}$ in the sample calculated by subtracting the free choline from the total choline.

\section{Materials and Reagents}

1. A549 cells (American Type Culture Collection)

2. Human Epidermal Growth Factor (EGF) (Sigma Chemical, catalog number: E9644)

3. 100x Insulin Transferrin Selenium (ITS) (Life Technologies, catalog number: 41400-045)

4. Rosewell Park Memorial Institute (RPMI) Medium -1640 (ATCC, catalog number: 41400045)

5. $50 \mu \mathrm{M}$ Hydrocortisone (Sigma-Aldrich, catalog number: H6909)

6. Boveine serum albumin (BSA) (US Biochem, catalog number: 10857)

7. Disposable sterile tissue culture filters (Corning, catalog number: 431161)

8. Choline/acetylcholine Quantification Kit (BioVision, catalog number: K615-100)

9. Liquid nitrogen

10. Serum-Free RPMI (SF-RPMI) (see Recipes)

11. Neostigmine (Sigma Chemical, catalog number: N2001) (see Recipes) 


\section{Equipment}

1. $60 \mathrm{~mm}$ cell culture dishes (Corning, catalog number: 353002)

2. Microfuge tube

3. ELISA Reader

4. Lyophilizer (Labonco)

5. Centrifuge

6. $\mathrm{CO}_{2}$ cell culture incubator

7. $-80^{\circ} \mathrm{C}$ freezer

\section{Procedure}

1. A549 cells were grown in $5 \mathrm{ml}$ serum-free RPMI (SF-RPMI) to $90 \%-95 \%$ confluence in 60 $\mathrm{mm}$ cell culture dishes in a cell culture incubator set at $5 \% \mathrm{CO}_{2}$ and $37{ }^{\circ} \mathrm{C}$ (Lau et al., 2013; Song et al., 2008; Song et al., 2003).

2. On the day of the assay, $100 \mu \mathrm{M}$ neostigmine (a chemical inhibitor of AChE in cells) was added to each plate for four hours at $37^{\circ} \mathrm{C}$. The plate contained $3 \mathrm{ml}$ of media. Please see Notes section about optimization of the concentration of neostigmine.

3. Four hours after the addition of neostigmine, the relevant concentration of test compund (which promotes/inhibits the secretion of ACh) was added and the cells were incubated at $37{ }^{\circ} \mathrm{C}$ for $36 \mathrm{~h}$. An example of a compound which promotes the production of ACh is 100 $\mathrm{nM}$ nicotine.

4. The supernatant (medium) was collected and spun at $800 \times \mathrm{g}$.

5. The supernatants were frozen at $-80^{\circ} \mathrm{C}$ and then lyophilized. The lyophilizer was set to a pressure of 10 micron $\mathrm{Hg}$ or below that value. The samples were lyophilized overnight.

6. Subsequently, the lyophilizate was reconstituted with $1 / 5$ volume autoclaved water (600 $\mu \mathrm{l}$ autoclaved water), snap frozen in liquid nitrogen and stored at $-80{ }^{\circ} \mathrm{C}$ until further analysis.

7. The amount of ACh in the sample was measured using the Choline/acetylcholine Quantification Kit, according to manufacturer's instructions (http://www.biovision.com/choline-acetylcholine-quantification-colorimetric-fluorometrickit-2910.html). The protocol outlined in the assay kit will be attached here. Each sample was assayed in triplicate. 


\section{$\underline{\text { Notes }}$}

ACh is secreted by lung cancer cells into the extracellular environment. Part of the ACh binds to nicotinic acetylcholine receptors and muscarinic acetylcholine receptors on the same lung cancer cells stimulating their proliferation in an autocrine manner. The excess ACh is quickly degraded by the enzyme $A C h E$ to generate choline which is then taken up by the cells to synthesize new ACh. Therefore, it is essential to inhibit the AChE to measure the ACh produced by the lung cancer cells.

Optimization of the concentration of neostigmine:

1. Neostigmine is added to inhibit the enzyme AChE in cells. It is important to titrate the amount of neostigmine to be used otherwise it may compromise the readout of the assay.

2. A549 cells were grown in serum-free RPMI (SF-RPMI) to $90 \%-95 \%$ confluence in $60 \mathrm{~mm}$ cell culture dishes in a cell culture incubator set at $5 \% \mathrm{CO}_{2}$ and $37{ }^{\circ} \mathrm{C}$.

3. On the day of the assay, the following concentrations of neostigmine were added
a. $10 \mu \mathrm{M}$
b. $20 \mu \mathrm{M}$
c. $50 \mu \mathrm{M}$
d. $100 \mu \mathrm{M}$
e. $200 \mu \mathrm{M}$
f. $\quad 300 \mu \mathrm{M}$

4. Each plate contained $3 \mathrm{ml}$ of media. The cells were incubated at $37^{\circ} \mathrm{C}$ for $36 \mathrm{~h}$.

5. Follow the steps 4-7 of the Procedure section described above.

6. In our experiments, the production of $A C h$ varied with increasing concentrations of neostigmine as shown below in Figure $1 \mathrm{~A}$. Figure $1 \mathrm{~B}$ shows that the amount of AChE in all three cell lines is similar. The baseline amount of ACh is highest in the presence of 100-200 $\mu \mathrm{M}$ neostigmine. Therefore, we selected $100 \mu \mathrm{M}$ neostigmine for all our experiments. It is probable that $300 \mu \mathrm{M}$ of neostigmine is toxic so the cells and causes cell death so the levels of ACh are lower. 


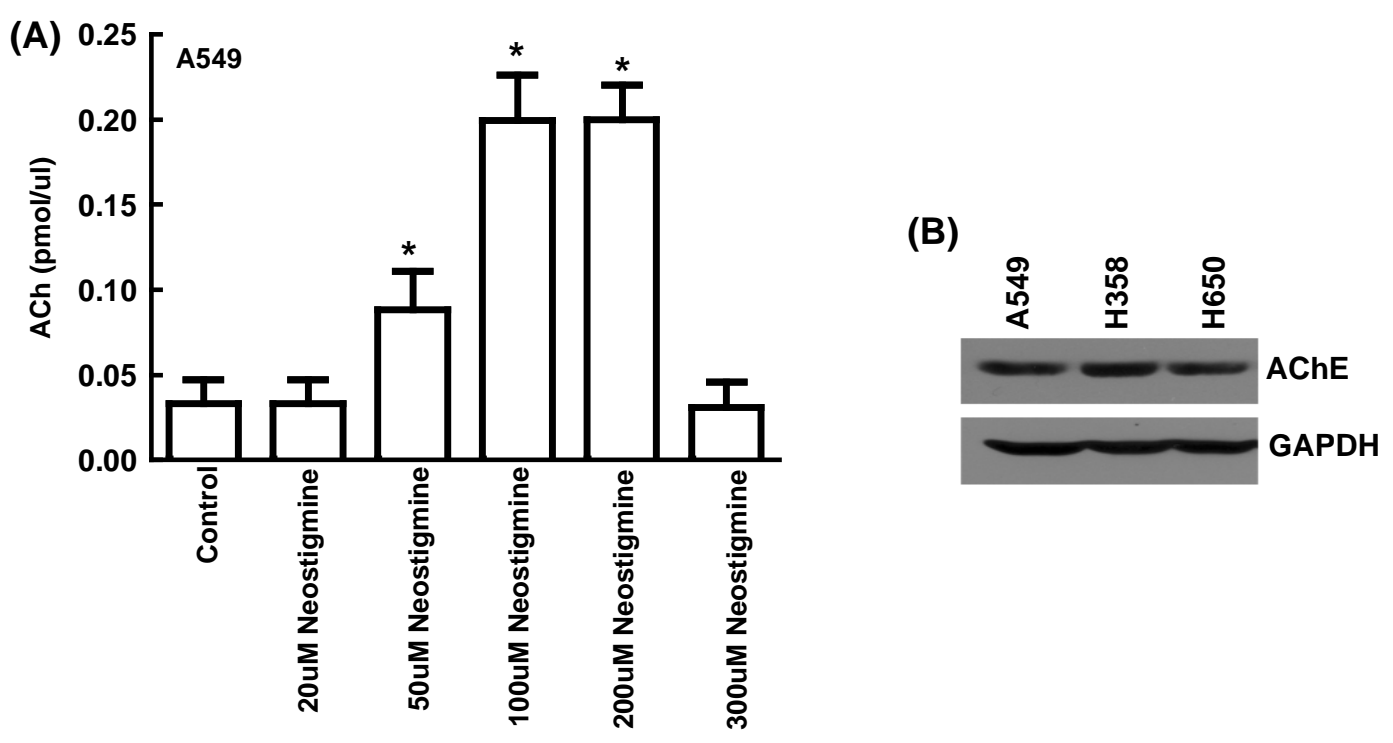

Figure 1. Optimization of the concentration of neostigmine for measurement of ACh from A549 human lung cancer cells. (A) A549 human lung cancer cells were cultured in SF-RPMI and the amount of ACh produced was measured in the presence of varying concentrations of neostigmine. The baseline amount of $\mathrm{ACh}$ is highest in the presence of 100-200uM neostigmine. (B) Western blotting analysis shows the presence of robust amounts of AChE in three human lung cancer cell lines namely A549, H358 and H650. Values indicated by the * are statistically significant relative to controls ( $\left.{ }^{*} P<0.05\right)$.

\section{$\underline{\text { Recipes }}$}

1. Serum-Free RPMI (SF-RPMI), $100 \mathrm{ml}$

To $50 \mathrm{ml}$ of RPMI in a sterile bottle, add the following:

$100 \mathrm{mg} \mathrm{BSA}$ to and stir to dissolve

$1 \mathrm{ml}$ ITS

$100 \mathrm{ul}$ of $50 \mathrm{uM}$ hydrocortisone

$1 \mathrm{mg}$ EGF

Make up the volume to $100 \mathrm{ml}$ with RPMI

Filter sterilize using a $0.22 \mu \mathrm{m}$ filter

Stored at $4{ }^{\circ} \mathrm{C}$

2. Neostigmine (Stock $=100 \mathrm{mM}$ )

Weigh $33.4 \mathrm{mg}$ of neostigmine in a sterile microfuge tube

Dissolve it in autoclaved water

Aliquot in multiple microfuge tubes

Stored at $-20^{\circ} \mathrm{C}$ 


\section{Acknowledgments}

We would like to acknowledge the following publications on which this protocol is based: Song et al. (2008); Song et al. (2003a); Song et al. (2003b). We thank Dr. Srikumar Chellappan and his laboratory for their continuous support. This work was supported by the grants Young Clinical Scientist Award (\#82115) from the Flight Attendant Medical Association, Miami, FL and 1R15CA161491-01A1 from NIH to PDG. KCB is a recipient of a graduate fellowship from the WVSGC.

\section{References}

1. Cancer, I.A.R.C. (2004). IARC Monographs on the Evaluation of Carcinogenic Risks to Humans. In Tobacco Smoke and Involuntary Smoking: IARC, Lyon, France. 51-1187.

2. Lau, J. K., Brown, K. C., Thornhill, B. A., Crabtree, C. M., Dom, A. M., Witte, T. R., Hardman, W. E., McNees, C. A., Stover, C. A., Carpenter, A. B., Luo, H., Chen, Y. C., Shiflett, B. S. and Dasgupta, P. (2013). Inhibition of cholinergic signaling causes apoptosis in human bronchioalveolar carcinoma. Cancer Res 73(4): 1328-1339.

3. Song, P., Sekhon, H. S., Fu, X. W., Maier, M., Jia, Y., Duan, J., Proskosil, B. J., Gravett, C., Lindstrom, J., Mark, G. P., Saha, S. and Spindel, E. R. (2008). Activated cholinergic signaling provides a target in squamous cell lung carcinoma. Cancer Res 68(12): 46934700.

4. Song, P., Sekhon, H. S., Jia, Y., Keller, J. A., Blusztajn, J. K., Mark, G. P. and Spindel, E. R. (2003a). Acetylcholine is synthesized by and acts as an autocrine growth factor for small cell lung carcinoma. Cancer Res 63(1): 214-221.

5. Song, P., Sekhon, H. S., Proskocil, B., Blusztajn, J. K., Mark, G. P. and Spindel, E. R. (2003b). Synthesis of acetylcholine by lung cancer. Life Sci 72(18-19): 2159-2168.

6. The HEALTH Consequences of Smoking. (2004). A report of the Surgeon General's Office on Smoking and Health, DHHS, Washington DC. 